\title{
Huntington's disease in monozygotic twins reared apart
}

\author{
LEWIS SUDARSKY*+, RICHARD H MYERS $\dagger_{+}^{+}$, AND THOMAS M WALSHE*+
}

From *the Neurology Service, VA Medical Centers, West Roxbury and Brockton, and

the Departments of Neurology, $\dagger$ Boston University School of Medicine, and

${ }_{\dagger}^{+}$Harvard Medical School, Massachusetts, USA.

SUMmaRY Monozygotic twins, identical by serological studies, with Huntington's disease are described who were raised in separate households from birth. Age at onset, landmarks of the disease, and behavioural abnormalities were strikingly similar. Previously reported twin studies in Huntington's disease are reviewed. Twin data support the hypothesis that age at onset and several other clinical features of the illness are substantially determined by genetic mechanisms.

Huntington's disease (HD) displays remarkable variability in age of onset. ${ }^{1}$ Comparisons of monozygotic and dizygotic twins are useful in assessing the influences of heredity and environment on the onset and clinical course of the illness. Thirteen sets of monozygotic twins with HD have been reported; eight sets $^{2-8}$ were presumed to be identical by physical characteristics and five sets ${ }^{9-13}$ were proved identical serologically. Five sets of reported dizygotic twins were discordant for $\mathrm{HD}^{14-18}$ and only one dizygotic twin pair was concordant. ${ }^{3} 19$

We describe serologically proven monozygotic twins who were raised in different homes from birth. The family is of Greek ancestry and the pedigree is presented in the figure. Twin 1 was born first and was raised as an only child by a biological paternal uncle and his wife. Twin 2 was raised in the home of his biological parents as the sixth of seven children. The twins lived in the same community and learned that they were twins, not cousins, when they were enrolled in the same first grade class and their physical resemblance made it necessary to divulge their relationship. The biological father of the twins developed HD in his early thirties and died at the age of 42. The adoptive father of twin 1 retired as a barber at the age of 40 . He subsequently developed Huntington's disease also, but had no severe symptoms until the age of 63 and lived to 83 . Although the twins knew one another growing up, there were substantial differences in their upbringing, education, and later life experiences. Twin 2 was

Received for publication 8 April 1983.

Accepted for publication 5 May 1983. never married and his subsequent work history was much more erratic.

\section{Case reports}

\section{TWIN 1}

Twin 1 first came to medical attention aged 39, whe chorea was noted during a routine annual physical at work. There was a 10-year history of aggressive outbursts and moodiness, and a 4-year history of movements involving the hands. Family history was reviewed and a diagnosis of Huntington's disease was made. At the age of 42 he was admitted to a state hospital following two episodes of violent behaviour, each precipitated by drinking. Chlorpromazine was started.

At the age of 44, twin 1 was admitted to Brockton VA Medical Center for severe behaviour problems. Decline in mental state had made home care a formidable chore for his wife. Examination revealed $₹$ inattention and inappropriate lack of concern. He had telegraphic, dysarthric speech, but comprehension, repetition, and object naming were good. Diffuse chorea and bilateral ankle clonus were noted. Several episodes of aspiration necessitated a liquid $\sigma$ diet. He sustained falls and became incontinent. N An episode is recorded in which he assaulted a nurse. N At the age of 54 he appears gaunt at $59.8 \mathrm{~kg}$. He is a total care patient, requiring a nasogastric tube, $a \underset{<}{2}$ condom catheter, and restraints at times to prevent self-inflicted injuries. Speech is severely dysarthric, $\stackrel{\oplus}{\rightarrow}$ but occasional vocal utterances are made. There is no volitional lateral gaze, though doll's eye movements 408 


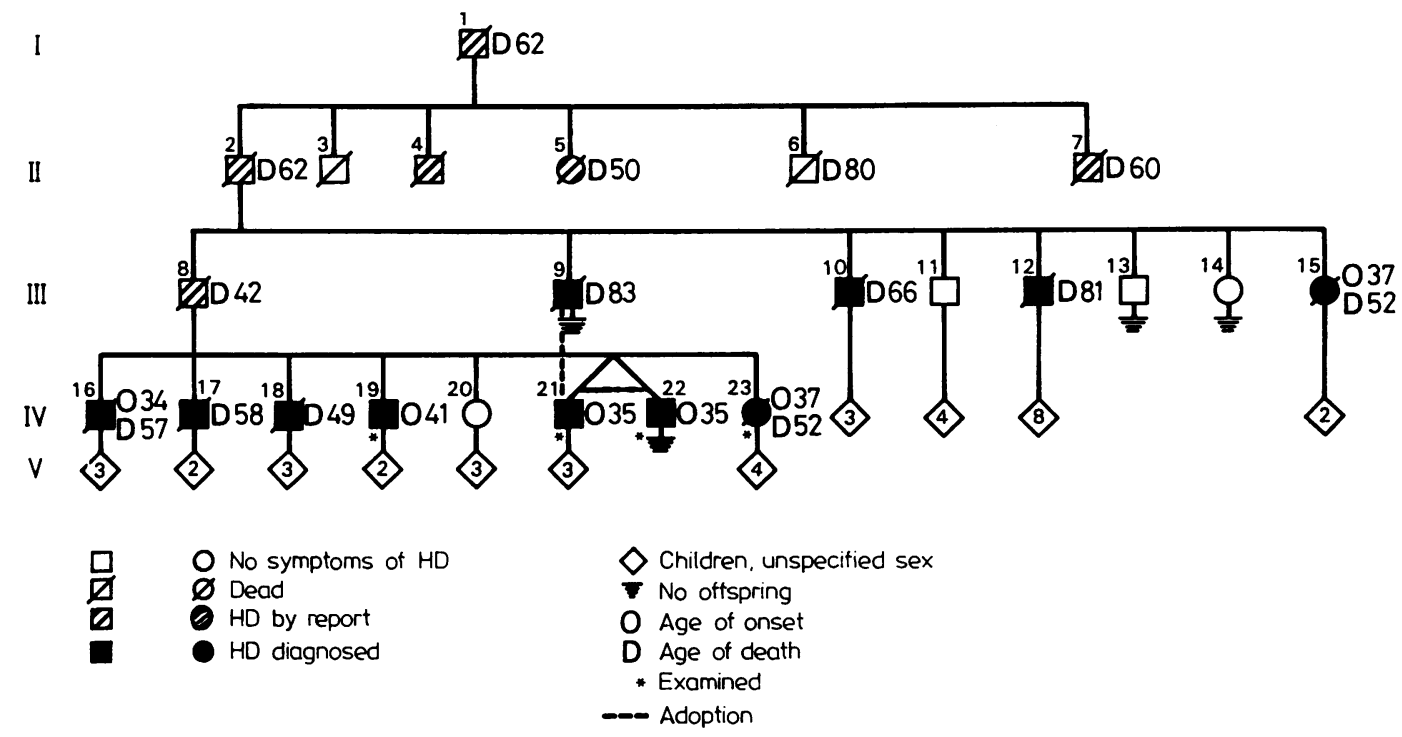

FIGURE The family pedigree reveals a strong history of Huntington's disease. Twin 1 (IV.21) was adopted by a paternal uncle (III.9) while twin 2 (IV.22) was raised by the biological parents. The biological father of the twins exhibited symptoms of HD in his mid-30s and died aged 42 while the adoptive uncle had HD diagnosed aged 63 and died aged 83. In spite of the differences in expression of $H D$ in the respective biological and adoptive fathers, the onset and course of the illness in the twins has been remarkably similar.

are full. Chorea is marked in the oral-buccal-lingual area and mild elsewhere. There is marked rigidity and dystonia, with a fixed fisted posture of the left arm and flexion of the lower extremities. Reflexes are $3+$ where elicitable and the right toe is extensor.

TWIN 2

Twin 2, the younger of the twins, received an honourable discharge from the Navy and worked at different jobs as a carpenter for 20 to 25 years. He never married. He had a history of arrests for alcoholism and other disturbances from the age of 20. His family declined to press charges for repeated episodes of assault involving his mother and sibs. His first admission to a psychiatric hospital was at the age of 42 for drunkenness. The family history of HD was known and choreic movements were evident at that time. Six months after discharge he was admitted to hospital again, following an assault on his mother with a kitchen knife. Twin 2 has resided at the VA Medical Center, Brockton, since his transfer from a state hospital at the age of 44 . The admitting physician reported active psychotic delusions. (The patient was seeing himself on TV and claimed that he had been paid by the President to sire children for him.) Neurological evaluation revealed disorientation and severe dysarthria. He was unable to walk unassisted and chorea was marked. He had brisk, symmetrical tendon reflexes and upgoing toes. Chlorpromazine $600 \mathrm{mg} /$ day was required for aggressive behaviour.

Twin 2 is thin, has a feeding gastrostomy, and a Foley catheter. The blood pressure is $120 / 75$. He is mute and interacts minimally. There is a paucity of volitional lateral gaze, though doll's eye movements are full and Bell's phenomenon is preserved. Corneal responses are equal and gag is difficult to elicit. There are prominent perioral choreic movements involving the lips, tongue, and face. In addition to marked stiffness and flexion in the lower extremities, there is fixed dystonia of the right upper extremity. The left hand is fisted. Chorea, which is prominent in the trunk and extremities, is more pronounced than in his twin. Reflexes are clonic at the knee and ankle and the toes are bilaterally extensor. Sensation to pinprick is preserved in the lower extremities.

\section{Discussion}

Huntington's disease, it has been said, runs to form in an affected kindred, ${ }^{20}$ yet striking variations are often observed within a single family. We note here the remarkable similarity of symptoms and course of 
illness for these twins in spite of their upbringing in separate family environments. Close physical resemblance and serological concordance for blood groups A, Duffy $\left(\mathrm{Fya}^{-}\right)$, Kell $\left(\mathrm{K}^{+}\right)$, Kidd $\left(\mathrm{Jka}^{+}\right)$, and $\mathrm{Rh}$ (CcDee) produce a $99.6 \%$ probability of monozygosity $^{21}$ for gene frequencies in Greece. ${ }^{22}$ Shoulson ${ }^{23}$ has documented a characteristic rate of decline in the functional capacity of HD patients which is comparable to the parallel progression which these twins have experienced. The table lists landmarks in the medical history. Both twins had early dysarthria and both exhibited small twitches of the hands and fingers at the age of 35 . Both required institutional care within 6 months of each other. Twin 1 manifests more rigidity and dystonia and less chorea than twin 2 but the differences are only in degree. Both have pyramidal tract signs and both now manifest a prominent eye movement disorder. Both have the 'paraplegia in flexion' common in chronic patients with advanced disease. ${ }^{24}$

Although the biological father of the twins and his brother, who adopted twin 1 at birth, both developed $\mathrm{HD}$, the expression was very different in that the biological parent developed debilitating symptoms nearly 30 years younger than his brother. Thus, the striking similarity for the twins in the age at onset of choreiform movement and in the nature of behavioural manifestations of the disease, in spite of the differences in expression for the parents and of environmental differences in childhood and adolescence, provides a lesson in the occasional biological determinants of human behaviour. Both twins have a

TABLE Landmarks in the twins' medical history.

\begin{tabular}{|c|c|c|}
\hline & Twin 1 & Twin 2 \\
\hline Home & $\begin{array}{l}\text { Raised by paternal } \\
\text { uncle as only } \\
\text { child }\end{array}$ & $\begin{array}{l}\text { Raised by biological } \\
\text { parent as } 6 \text { th of } 7 \\
\text { children }\end{array}$ \\
\hline $\begin{array}{l}\text { Expression of HD } \\
\text { in parent }\end{array}$ & $\begin{array}{l}\text { Adoptive uncle } \\
\text { diagnosed HD } \\
\text { aged } 63 \text {, died } \\
\text { aged } 83\end{array}$ & $\begin{array}{l}\text { Biological father } \\
\text { initial signs of HD } \\
\text { in mid } 30 \mathrm{~s} \text {, } \\
\text { died aged } 42\end{array}$ \\
\hline Education & $\begin{array}{l}\text { Finished high school } \\
\text { aged } 18,1 \text { year } \\
\text { electrician school }\end{array}$ & $\begin{array}{l}\text { Did not finish high } \\
\text { school }\end{array}$ \\
\hline Marriage & Married aged 26 & Never married \\
\hline Employment & 15 years at same job & 20 years carpentry \\
\hline $\begin{array}{l}\text { First behavioural } \\
\text { symptoms }\end{array}$ & 1957 (29) & $1948(20)$ \\
\hline $\begin{array}{l}\text { Onset of choreic } \\
\text { movements }\end{array}$ & $1963(35)$ & $1963(35)$ \\
\hline $\begin{array}{l}\text { First admission } \\
\text { to psychiatric } \\
\text { hospital }\end{array}$ & $\begin{array}{l}\text { August } \\
1970(42)\end{array}$ & $\begin{array}{l}\text { July } \\
1970(42)\end{array}$ \\
\hline Chronic care & $\begin{array}{l}\text { March } \\
1972(44)\end{array}$ & $\begin{array}{l}\text { May } \\
1971(43)\end{array}$ \\
\hline $\begin{array}{l}\text { Chlorpromazine } \\
\text { instituted }\end{array}$ & $1970(42)$ & $1973(45)$ \\
\hline $\begin{array}{l}\text { Required assistance } \\
\text { to walk }\end{array}$ & $1972(44)$ & $1973(45)$ \\
\hline Total bed care & $1978(48)$ & $1978(48)$ \\
\hline Nutritional failure & 1979 (49) & 1979 (49) \\
\hline
\end{tabular}

history of difficulties with the law, aggressive behaviour requiring major tranquillisers, and trouble with alcohol. That twin 1 exhibited this behaviour 9 years after twin 2 may reflect a stabilising effect of his marriage and work environment. Neither has had prominent affective symptoms, and neither was treated with anti-depressants. The mental status examination of twin 1 revealed classic frontal dementia, including features of unconcern and irritability, with the relative preservation of language and memory. A thought disorder was described in twin 2, who exhibited manneristic thinking and grandiose delusions. When he was lucid, however, he was also observed to have poor judgment with relative preservation of memory and language, features suggesting a frontal or subcortical dementia.

Hayden $^{25}$ has recently reviewed the ages of onset for 13 sets of $\mathrm{MZ}$ twins reported. There is close agreement in the age of onset for all twin pairs. The within-pair difference in onset age ranges from 0 to 3 years with an average difference of less than 1 year. Within this group are reported two sets of $\mathbf{M Z}$ twins with similar ages of onset but with discordant clinical expression of HD, one twin having a greater degree of rigidity than the co-twin. ${ }^{12} 13$

A single pair of DZ twins concordant for HD has been reported. ${ }^{319}$ The difference in age of onser between these twins is 7 years. This difference is substantially greater than that separating any reported MZ twins, and is similar to the difference in age of onset found between full sibs and first degree relatives.

Although the number of twin case reports is small, these data support the view that the age of onset and many clinical features of HD are substantially determined by genetic mechanisms. Our explanation is that a discrete number of additional genes migh modify the expression of the gene for HD. It has recently been reported that some HD carriers do not exhibit symptoms until the sixth decade of life. ${ }^{26}$ The wide variation in age of onset indicates that the HD gene is susceptible to biological manipulation, which has implications for the treatment of this and other age-related diseases.

This work was supported in part by the Huntington's Disease Center Without Walls (PHS Grant NS 16367).

\section{References}

1 Myers RH, Madden JJ, Teague JL, Falek A. Factors related to onset age of Huntington's disease. Am J Hum Genet 1982;34:481-8.

2 Russell JW. Two cases of hereditary chorea, occurring in twins. Birm Med Rev 1894;35:31-3. 
3 Rosanoff AJ, Handy LM. Huntington's chorea in twins. Arch Neurol 1935;33:839-41.

4 Entres JL. Der Erbreitstanz (Huntingtonsche Chorea). In: Gutt A, ed. Handbuch der Erbkrankheiten. Leipzig: Thieme, 1940:243-62.

5 Jequier M. La choree de Huntington. Arch Julius Klaus Stift 1945;20:77-208.

6 Jelgersma HC. Monozygotic twins with concordant Huntington's chorea and discordant hemiplegia. Folia Psychiatr Neurol Neerl 1957:60;50-2.

7 Parker N. Observations on Huntington's chorea based on a Queensland survey. Med J Aust 1958;1:351-9.

8 Bachman DS, Butler IJ, McKhann GM. Long-term treatment of juvenile Huntington's chorea with dipropylacetic acid. Neurology (Minneap) 1977;27:193-7.

9 Myrianthopoulos NC, Rowley PT. Monozygotic twins concordant for Huntington's chorea. Neurology (Minneap) 1960;10:506-11.

${ }^{10}$ Schiottz-Christensen E. Chorea Huntington and epilepsy in monozygotic twins. Eur Neurol 1969;2:250-5.

11 Husquinet H, Franck G, Vranckx C. Detection of future cases of Huntington's chorea by the L-DOPA load test: experiment with two monozygotic twins. Adv Neurol 1973;1:301-10.

12 Oepen H. Discordant features of monozygotic twin sisters with Huntington's chorea. Adv Neurol 1973;1:199-201.

13 Bird TD, Omenn GS. Monozygotic twins with Huntington's disease in a family expressing the rigid variant. Neurology (Minneap) 1975;25:1126-9.

14 Kalkhof J, Ranke O. Eine neue chorea Huntingtonfamilie. $Z$ Ges Neurol Psychiatr 1913;17:256-304.

15 Rosenthal C. Zur Symptomatologie und Fruhdiagnostik der Huntingtonshem Krankheit, zugleich ein Beitrag zur klinischen Erbforschung. Z Ges Neurol Psychiatr 1927; $111: 254-69$.
16 Wasum K. Chorea Huntington-Sippe. Arch Psychiatr Nervenkr 1935;103:78-100.

17 Perrine GA, Goodman RM. A family study of Huntington's chorea with unusual manifestations. Ann Intern Med 1966;64:570-4.

18 Bolt JMW. Huntington's chorea in the West of Scotland. BrJ Psychiatry 1970;116:259-70.

19 Owensby NM. Huntington's chorea in a twin child. J Nerv Ment Dis 1925;61:466-70.

${ }^{20}$ Bruyn GW. Huntington's chorea. In: Vinken PJ, Bruyn GW, eds. Handbook of clinical neurology. Vol 6. Amsterdam: North Holland, 1968:298-378.

${ }^{21}$ Cavalli-Sforza LL, Bodmer WF. The genetics of human populations. San Francisco: Freeman, 1971.

22 Mourent AE, Kopec AC, Domaniewska-Sobczak K. The distribution of the human blood groups and other polymorphisms. London: Oxford University Press, 1976.

23 Shoulson I. Huntington's disease. Functional capacities in patients with neuroleptic and antidepressant drugs. Neurology (Minneap) $1981 ; 31: 1333-5$.

24 Yakovlev P. Paraplegia in flexion of cerebral origin. J Neuropathol Exp Neurol 1954;13:267-96.

${ }^{25}$ Hayden MR. Huntington's chorea. New York: SpringerVerlag, $1981: 54-5$.

${ }^{26}$ Sax DS, Myers RH, Wolf PA, Bird ED, Schoenfeld M. Late onset Huntington's disease. Neurology (Minneap) $1982 ; 11: 186$ A.

Correspondence and requests for reprints to Dr Richard H Myers, Department of Neurology, Boston University Medical Center, Boston, Massachusetts 02118, USA. 